\title{
INFORMATION MEASURING SYSTEM FOR CORRECTION OF WORKING MEMORY PARAMETERS IN THE LEARNING PROCESSES
}

\author{
A.A. Petrenko, a.a.petrenko@urfu.ru, \\ V.S. Kublanov, kublanov@mail.ru \\ Ural Federal University named after the first President of Russia B.N. Yeltsin, \\ Ekaterinburg, Russian Federation
}

\begin{abstract}
This paper presents the results of a system analysis of the information-measuring system (IMS) for correction of the working memory parameters of subjects during the learning process, in which the neuroplasticity of the brain is triggered by stimulating the nerve formations of the neck of a spatially distributed field of voltage impulses, the target of stimulation is the cervical ganglia of the sympathetic nervous system, control of functional changes in the body is carried out according to changes in the parameters of the blood supply system, and psychometric tests are used to assess working memory parameters. Aim. Development of IMS, using neuroelectrostimulation of peripheral nerve formations of the neck for correction of working memory parameters in the learning process. Materials and methods. The study involved 65 subjects, divided by randomization into experimental, control and placebo groups. Working memory parameters were assessed using the dual 2-back test, and the functional state was assessed using heart rate variability (HRV) analysis. Results. The results of the study showed that the proposed structure of the IMS and the method of correction working memory allow to improve the working memory parameters and normalize state of the autonomic nervous system after three correction procedures. The obtained test results practically do not change and are saved after 2 months. Conclusion. IMS, which provides multichannel neuroelectrostimulation of peripheral nerve formations in the neck, is effective for correction of cognitive skills, which is important for solving problems in the field of education.

Keywords: information measuring system, neuroelectrostimulation, system analysis, information, methods and algorithms, cognitive characteristics, working memory.
\end{abstract}

\section{Introduction}

At the present stage of science and technology progress, in the context of the integration of the latest technologies, a person must have the ability to materialize his capabilities for active participation in social life. In this process, a special role is assigned to the development of learning technology, and the assessment of individual human learning abilities. In connection with the rapid development of the technical component of complex systems against the background of a decrease in the general educational level of training, ensuring effective training of specialists in complex technical systems is currently becoming an urgent task [1].

Learning disabilities can lead to poor performance in the child (student), which is unexpected when considering their potential, intelligence quotient (IQ), quality of the learning process, intact sensory system, adequate motivation, and appropriate learning conditions.

It is worth noting that learning disabilities are specific in the sense that they affect certain areas of information processing (for example, reading, writing and math), in contrast to the global difficulties seen in children with intellectual disabilities. Although they have medium to high IQ, people with disabilities do not learn as quickly as others. This indicates that their problem cannot be simply explained by an impaired intellectual development, the reasons may be more complex phenomena that should be paid attention to [2].

People with learning disabilities may have deficits in one or more cognitive processes [3], including phonological processing, long-term information retrieval, attention, short-term memory, and working memory. Among several cognitive processes, working memory was found to be closely related to aca- 
demic skills. Numerous studies have shown a strong relationship between working memory performance, reading skills and performance in mathematics [4].

Some researchers [5] suggest that working memory is even more important for learning than IQ, as it is the best indicator of learning. It has been shown that IQ is a measure of what a person has already learned, while working memory measures learning ability (actual learning potential).

As an empirical characteristic of a person's ability to learn, learnability includes many indicators and parameters of a person's identity. These include, first of all, human cognitive capabilities (features of sensory and perceptual processes, memory, attention, thinking and speech), personality traits - motivation, character, emotional manifestations [6]. Various parts of the brain are involved in these processes, as well as various regulatory systems of the human body, of which the autonomic nervous system (ANS) is the most significant. To quickly understand and evaluate information at performing complex actions, the brain integrates complex and varied input signals from several sensory systems at the same time. The interconnection of these systems is carried out through the work of neural networks [7].

According to one of the key principles of the neuroscience, our brains are plastic and constantly change as a result of learning. In the process of learning, a person's cognitive reserve and adaptive responses to stress, traumatic events and diseases are formed. Thus, learning problems reflect the inefficient use of the resources that the brain possesses [8]. The idea of activating these resources in order to increase the speed and efficiency of training arises.

There are prerequisites that the combination of neurostimulation of the peripheral nervous system with traditional learning methods will allow the use of an endogenous neural circuit to improve the quality of learning by accelerating the tuning of neural networks responsible for cognitive functions [7]. Therefore, it is of interest to explore the possibilities of such an approach to improve the quality of learning.

This work presents the results of the IMS system analysis for correction of working memory parameters during the learning process, in which the neuroplasticity of the brain is triggered by stimulating the neural formations of the neck with a spatially distributed field of voltage impulses, and the target of stimulation is the cervical ganglia of the sympathetic nervous system [ 9], the control of human functional changes is carried out according to heart rate variability (HRV) changes, and dual 2-back test are used to assess the working memory parameters.

\section{The structure of the information measurement system}

To organize information measurement system (IMS), we will use the theory and technology of biotechnical systems, which are a set of biological and technical elements interconnected in a single control loop [10]. To the same extent, biotechnical systems include both systems in which a person plays the role of a control link and technical systems that control the human body to solve specific problems.

IMS for the correction of working memory parameters in the learning process belongs to the second type of systems. Usually a person in this position is defined as a human operator, and the effectiveness of such systems depends on how ready he is to perceive the external world and make the right decisions [11]. When solving these problems, not only technical means are used, but also psychometric techniques, as well as methods of functional studies of the human condition. An indispensable condition for the optimal functioning of biotechnical systems are the principles of the adequacy of the coordination of the "management" characteristics of the technical and biological elements of the system and the principle of identifying the information environment, which requires optimization of the intensity of flows and the form of presentation of information, which are exchanged during the operation of technical and biological elements of the system [12].

Accordingly, the IMS block diagram for correction of working memory parameters can be presented as in Fig. 1.

The features of the organization and the tasks performed by units included in the IMS are considered below. 


\section{Инфокоммуникационные технологии и системы}

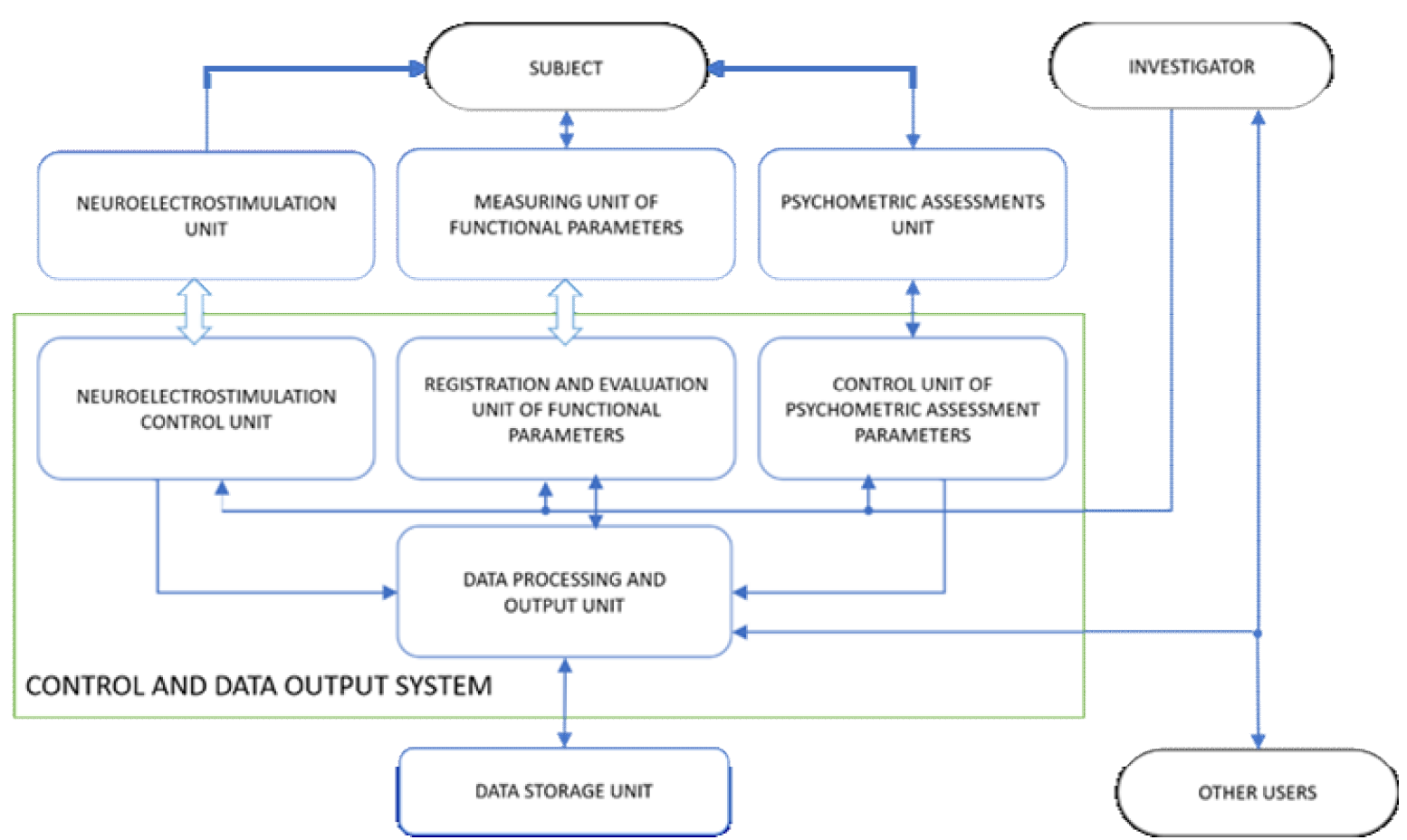

Fig. 1. Block diagram of the information measuring system structure

\subsection{Neuroelectrostimulation unit}

Depending on the tasks of the study, the neuroelectrostimulation unit can have two realizations of the structure of voltage pulse sequences that provide electrical stimulation of the nerve formations of the neck: a multi-channel spatially distributed field of impulses, the target of which is the cervical ganglia of the sympathetic nervous system; a sequence of impulses between two electrodes - in this case,

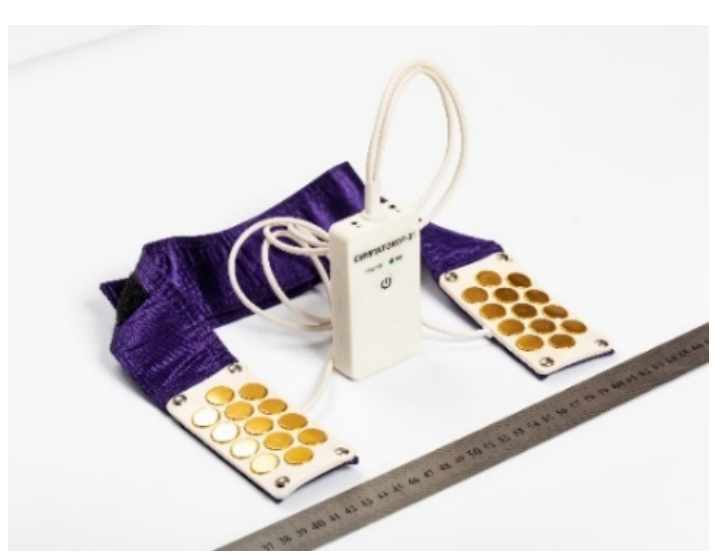

Fig. 2 The general view of the "SYMPATHOCOR-01" device the target of stimulation is one of the areas of the neck in which the presence of fibers of the sympathetic nervous system is minimal.

For the formation of different structures of impulse sequences in the IMS, a neuroelectrostimulator device "SYMPATHOCOR-01" was used [13]. General view of the "SYMPATHOCOR-01" device is shown in Fig. 2.

The formation of a spatially distributed field of voltage pulses occurs between 13 electrodes of one of the multi-element electrodes (cathodes) and one or more electrodes of the other (anodes). During one switching cycle of the cathodes, a "burst" of such pulses is formed, with a current flowing under each cathode during one partial pulse, and in the region under the anode during the entire "pack" of pulses. Thus, a spatially concentrated current structure is formed in the neck tissues under the anode for one period of formation of a "pack" of pulses, the duration of which depends on the sum of the durations of 13 partial voltage pulses. And in the cathode zone there is a spatially distributed current structure of 13 areas, each of which corresponds to the location of the partial cathode, and the duration of the partial current pulse depends on the duration of the partial pulse.

The device can form partial current pulses with an amplitude of up to $15 \mathrm{~mA}$, a duration of 15 to $60 \mu \mathrm{s}$ and a "pack" of pulses with a frequency of 5 to $150 \mathrm{~Hz}$.

The structure of impulse sequences, neuroelectrostimulation parameters and the treatment process are controlled through the neuroelectrostimulation control unit via the BlueTooth channel formed by the transmitting and receiving elements located in the "SYMPATHOCOR-01" device and a personal computer. 


\subsection{Measuring unit of functional parameters}

Measuring unit of functional parameters provides registration of biomedical signals that reflect the physical manifestations of the physiological processes of a living organism and can be measured and presented in a convenient form for processing using electronic means.

The learning process requires from the body not only high resistance to extreme influences, but also good plasticity, i.e. the ability to adapt (adapt) to new conditions of existence. In the course of such adaptation, a new functional system is formed, which requires a certain tension of regulatory systems, additional energy costs. This process also requires constant expenditure of functional reserves. Thus, the normal level of functioning of the main systems of the body can be maintained only if there is no overstrain of regulatory mechanisms and the functional reserve is not depleted.

It is known that the human nervous system is subdivided into central and peripheral [14]. The central one includes the brain and spinal cord, the peripheral one includes the spinal and cranial nerves. Separately, the ANS is also distinguished, which ensures the continuous functioning of autonomic processes in the body (digestion, heartbeat, respiration, urination, etc.). The ANS is represented by its own nerve plexuses and fibers near the organs. The higher control centers of this system are located in the spinal cord and brain.

It was shown in [15] that HRV analysis has the greatest diagnostic value in neuroelectrostimulation of nerve formations in the neck. At the same time, a significant improvement in the functional connections of the medial prefrontal cortex with the rest of the brain was noted, which indicates an improvement in the connectivity of the brain regions, especially due to the activation of the frontal cortex. To implement the functions of the measuring unit of functional parameters in the IMS, a portable electroencephalograph - analyzer "Encephalan-EEGR-19/26" is used, which allows registering an electrocardiogram (ECG) signal and analyzing of HRV. The measuring unit of functional parameters and the unit for registration and evaluating unit of functional parameters are connected and synchronized with each other into a single wireless network using BlueTooth technology.

\subsection{Psychometric Assessment Unit}

The block of psychometric assessments is presented in the form of an N-back test for assessing working memory. The N-back technique is a modern and highly effective way to train working memory [16-18].

In the study, the difficulty level was dual 2-back: subject works with a sequence of visual and auditory stimuli, presented one at each time interval. Subject must give an answer if the current stimulus coincides with the element presented 2 intervals ago.

According to the test results, total score was determined. The test is implemented as a Brain Workshop software application on a personal computer.

\subsection{Control and data output system}

The control and data output system is presented in the form of a personal computer with a set of software systems and includes 4 elements: a neuroelectrostimulation control unit, a registration and evaluation unit of functional parameters, a control unit of psychometric assessment parameters, a data processing and output unit. The neuroelectrostimulation parameters are controlled using a software application for a personal computer.

An example of a graphical interface for setting parameters is shown in Fig. 3. The application for the control panel allows in real time to change the structure of the pulse sequence, the amplitude, duration of partial current pulses, the frequency of formation of the "pack" of pulses, to change the stimulation target, to change the direction of the field during neuroelectrostimulation [13].

The control of the parameters of registration of functional parameters is implemented using the software application of the "EncephalanEEGR-19/26" complex, and the block of psychometric assessments is implemented through the Brain Workshop software application.

The data processing and output unit is presented in the form of software tools necessary for the analysis, processing and output of the ob-

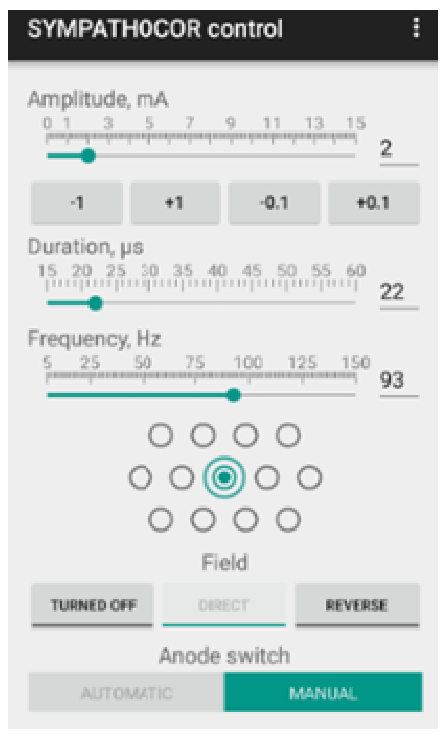

Fig. 3. Graphical interface for setting of neurostimulation parameters 


\section{Инфокоммуникационные технологии и системы}

tained data, implemented in the PYTHON programming language, and for statistical analysis, the STATISTICA 12.0 software was used.

The obtained data is sent to the data storage unit.

\subsection{Data storage unit}

A data storage unit is a cloud storage of a database. The database allows: to save the data set necessary for the IMS operation; displays them in an optimized way; provides fast search, reduces the time of access to the necessary information.

In the developed database, information is placed in the form of tables (entities), which store unique data sets of certain types. Instances of these entities act as rows of these tables, and their attributes act as columns. The developed database includes a set of textual, numerical and visual data that allows you to store general information about the research protocol, the name of the subject, the results of his testing, data of functional parameters, as well as the results of statistical data processing.

The database is available to the investigator at any stage of the research.

\section{Materials and methods}

The research was carried out at the Ural Federal University named after the first President of Russia B.N. Yeltsin.

The research involved 65 subjects aged 20 to 25 years, who gave informed consent to participate in the research.

The research consisted of 2 parts:

I part: primary assessment of the basic values of the dual 2-back test and the formation of groups of subjects to study the possibilities of correcting their working memory using IMS. Group formation was carried out by randomizing study participants to include them in one of three groups: experimental, placebo and control. As a result, the experimental group included 33 subjects, the control group - 22, placebo - 10 (Table. 1).

II part: carrying out a correction technique using the developed IMS.

When correcting working memory for the subjects of the experimental group, neuroelectrostimulation was used with a spatially distributed field of voltage pulses ( 5 procedures for 5 days).

The placebo subjects were stimulated using a pulsed voltage sequence generated between one anode and one cathode ( 5 treatments over 5 days).

For subjects of the control group, no stimulation was applied.

With the help of the measuring block of the IMS functional parameters, the ECG signal was recorded for the purpose of further analysis of the HRV parameters.

Description of the study groups

Table 1

\begin{tabular}{|l|c|l|}
\hline Group & Number of Subjects & \multicolumn{1}{|c|}{ Impact } \\
\hline Experimental & 33 & Neuroelectrostimulation \\
\hline Placebo & 22 & Placebo-stimulation \\
\hline Control & 10 & No stimulation \\
\hline
\end{tabular}

The sequence diagram of the one day of the study is presented in Table. 2.

Sequence diagram of the study

Table 2

\begin{tabular}{|c|c|c|c|c|}
\hline \multirow{2}{*}{ Stage } & \multicolumn{3}{|c|}{ Groups } & \multirow{2}{*}{$\begin{array}{c}\text { Time, } \\
\text { min }\end{array}$} \\
\hline & Experimental & Placebo & Control & \\
\hline 1 & \multicolumn{3}{|c|}{ Background } & 5 \\
\hline 2 & Neuroelectrostimulation + dual 2 back & Stimulation + dual 2 back & dual 2 back & 5 \\
\hline 3 & \multicolumn{3}{|c|}{ Rest } & 5 \\
\hline 4 & Neuroelectrostimulation + dual 2 back & Stimulation + dual 2 back & dual 2 back & 5 \\
\hline 5 & \multicolumn{3}{|c|}{ Aftereffect } & 5 \\
\hline
\end{tabular}




\section{Research results}

\subsection{Dual 2-back test results}

To assess changes in working memory parameters during the use of the developed IMS, an analysis of variance was carried out for the dual 2-back test parameters. The results are shown in Fig. 4.
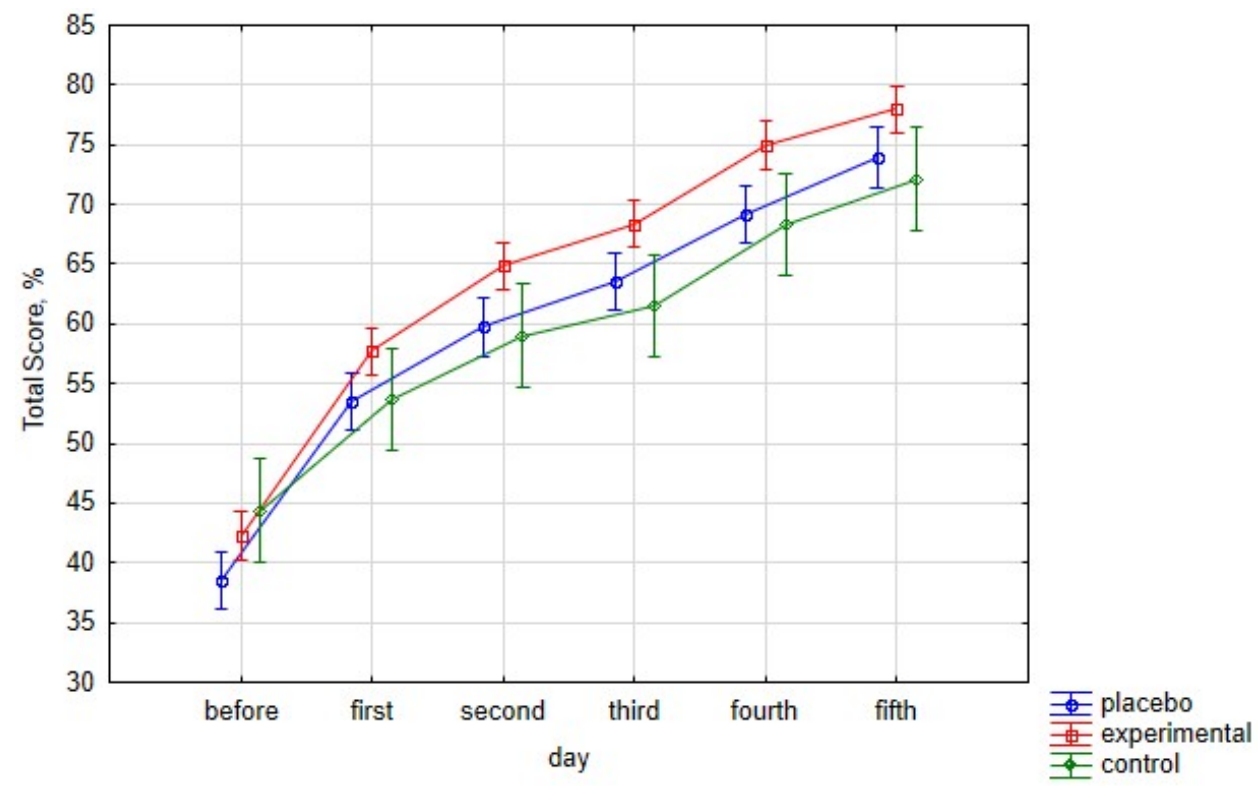

Fig. 4. Total score

According to the primary assessment of the dual 2-back test parameters, the average indicator of the total score in the three groups was $(41 \pm 1.9) \%$.

After the first procedure, the greatest increase in the indicator of the total score in all three groups is observed: the average indicator of the total score in the experimental group was $(58.5 \pm 1.9) \%$, in the control group $-(53.3 \pm 3,1) \%$, in the placebo group $-(52.7 \pm 2.1) \%$.

The greatest significant difference between the three groups is observed after the third procedure. The average indicator of the total score in the experimental group after the third procedure was $(69.6 \pm 1.8) \%$, in the control group $-(63 \pm 5.6) \%$, in the placebo group $-(63 \pm 2.3) \%$

\subsection{HRV data results}

In the experimental and placebo groups, in order to assess functional changes during the implementation of the correction technique of neuroelectrostimulation, the HRV parameters were analyzed on the fifth day of correction. In the course of data processing, the values of the Total Power (TP) of the spectrum, High Frequency - HF, Low Frequency - LF, Very Low Frequency - VLF spectral components, their normalized values $\mathrm{HF}_{\mathrm{nu}}=\mathrm{HF} \cdot 100 /(\mathrm{TP}-\mathrm{VLF}), \mathrm{LF}_{\mathrm{nu}}=\mathrm{LF} \cdot 100 /(\mathrm{TP}-\mathrm{VLF})$ and $\mathrm{VLF}_{\mathrm{nu}}=\mathrm{VLF} \cdot 100 /(\mathrm{TP}-\mathrm{VLF})$, as well as the vegetative balance index LF / HF were obtained. Within each group, the mean values of these parameters and the corresponding standard deviations were calculated. The results of analysis of variance of HRV data are presented in Figs. 5-7.

From the obtained data, it follows that in the experimental group during the 2 and 4 stages, which corresponds to the simultaneous action of neurostimulation and the performance of the dual 2 back test, there is a decrease in the $\mathrm{LF}_{\mathrm{nu}}$ component, an increase in the $\mathrm{HF}_{\mathrm{nu}}$ component and a decrease in the LF/HF. The increase in $\mathrm{HF}_{\mathrm{nu}}$ is associated with a decrease in sympathoadrenal activity and more pronounced vagal influences on the heart rate. A decrease in the LF/ HF index indicates the normalization of the vegetative balance.

In the placebo group, the opposite tendency is observed: during stages 2 and 4 , an increase in the $\mathrm{LF}_{\mathrm{nu}}$ component, a decrease in the $\mathrm{HF}_{\mathrm{nu}}$ component, and an increase in the LF/HF autonomic balance index are observed. An increase in the $\mathrm{LF}_{\mathrm{nu}}$ spectrum component predominantly characterizes the state of strengthening of the sympathetic center of vascular tone regulation. An increase in the LF/HF parameter indicates a vegetative disbalance. The placebo group is characterized by excessive activation of the sympathetic-adrenal system and a decrease in the activity of parasympathetic regulation. 


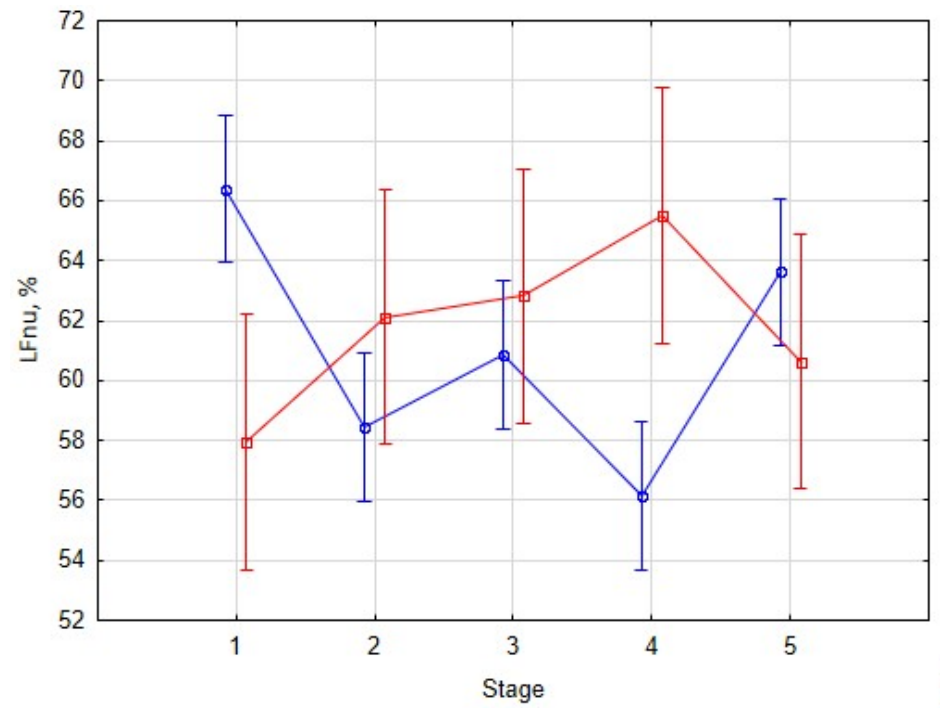

Fig. 5. LFnu component changes on fifth day

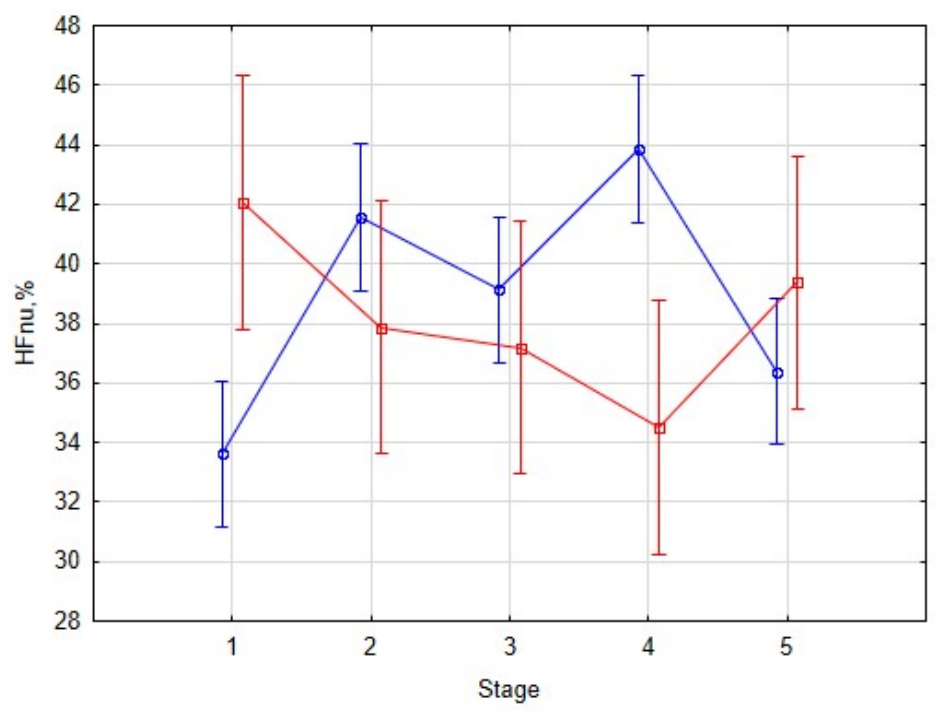

Fig. 6. HFnu component changes on fifth day

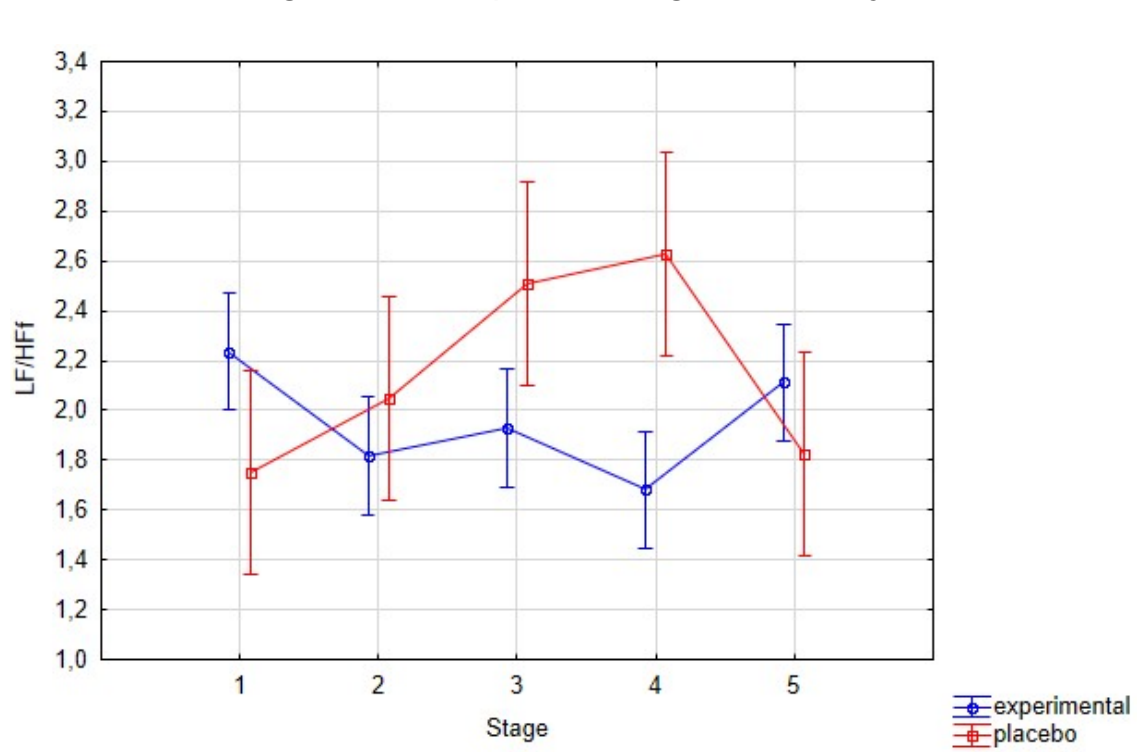

Fig. 7. LF/ HF changes on fifth day experimental placebo

छ experimental 曹 placebo क- placebo 


\subsection{Dual 2-back test results after 2 months}

At re-evaluating the test parameters after 2 months in the experimental group, the obtained results are preserved: after the fifth procedure, the values of the total score were $(78.4 \pm 1.8) \%$, after 2 months $(75.4 \pm 1.9) \%$ (Fig. 8 ).

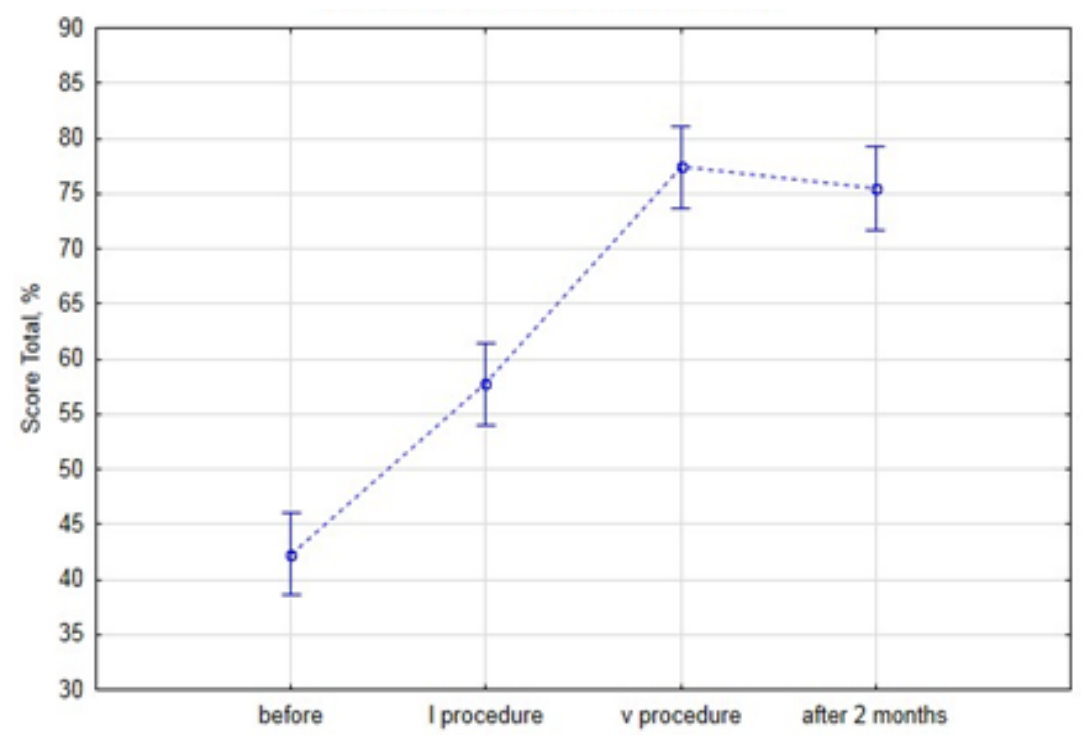

Fig. 8. Total score in experimental group after 2 months

\section{Conclusion}

The paper considers the possibilities of IMS for the correction of working memory parameters using neuroelectrostimulation of the peripheral nerve formations of the neck.

Shown, that:

- the proposed structure of the IMS provides the principles of the adequacy of the coordination of "management" characteristics and information flows of technical and biological elements of the IMS;

- application for stimulation of a spatially distributed field of voltage pulses formed in the "SYMPATHOCOR-01" device provides correction of working memory parameters in subjects whose total score of the dual 2-back test was below $47 \%$;

- significant intergroup differences in the parameters of the dual 2-back test are observed on the third day: the average indicator of the total score in the experimental group was $(58.5 \pm 1.9) \%$, in the control group $-(53.3 \pm 3.1) \%$, in the placebo group $-(52.7 \pm 2.1) \%$;

- results of the dual 2-back test in the experimental group are saved at a temporary distance: the values of the total score after 2 months changed insignificantly - from $(78.4 \pm 1.8) \%$ to $(75.4 \pm 1.9) \%$;

- it was found that with neuroelectrostimulation there is an increase in the activity of the parasympathetic nervous system of the body and the normalization of the autonomic balance.

The obtained results of the study can be applied in the development of new programs and methods of the educational process aimed at improving the quality of learning and the speed of mastering new skills.

\section{References}

1. Nalichaeva S.A. Psihologiya stressa [Psychology of stress]. Sevastopol, Avangard Publ., 2018. $97 \mathrm{p}$.

2. Gupta P.K., Sharma V. Working Memory and Learning Disabilities: A Review. The International Journal of Indian Psychology, 2017, vol. 4 (4), pp. 111-121. DOI: 10.25215/0404.013

3. Masoura E.V. Establishing the link between working memory function and learning disabilities. Learning disabilities. A contemporary journal, 2006, vol. 4 (2), pp. 29-41.

4. Swanson H.L., Howard C.B., Saez L. Do different components of working memory underlie different subgroups of reading disabilities? Journal of learning disabilities, 2006, vol. 39 (3), pp. 252-269. 


\title{
Инфокоммуникационные технологии и системы
}

5. Alloway T.P. Working memory, but not IQ, predicts subsequent learning in children with learning difficulties. European Journal of Psychological Assessment, 2009, vol. 25 (2), pp. 92-98. DOI: 10.1027/1015-5759.25.2.92

6. Lebedev A.V., Zhigalov Yu.A. Psihicheskie processy $i$ sostoyaniya [Mental processes and states]. St. Petersburg, 1999. 124 p.

7. Mandel' B.R. Sovremennaya pedagogicheskaya psihologiya [Modern educational psychology]. Moscow, Direkt-Media Publ., 2015. 828 p.

8. Brain Waves Module 2: Neuroscience: implications for education and lifelong learning. The Royal Society, 2011.

9. Kublanov V.S. [Electrophysical method for correcting violations of the cerebral blood supply regulation system]. Biomedical Radioelectronics, 1999, no. 4, pp. 12-15. (in Russ.)

10. Akulov S.A., Fedotov A.A. Osnovy teorii biotekhnicheskih sistem [Foundations of the theory of biotechnical systems]. Moscow, Fizmatlit Publ., 2014. 259 p.

11. Popechitelev E.P. Chelovek v biotekhnicheskoj sisteme [Human in biotechnical system]. Staryy Oskol, TNT Publ., 2016. 584 p.

12. Ershov Yu.A., Shchukin S.I. Osnovy analiza biotekhnicheskih sistem [Fundamentals of the analysis of biotechnical systems]. Moscow, Publishing house of Bauman Moscow State Technical University, 2011. $526 \mathrm{p}$.

13. Kublanov V.S., Babich M.V., Petrenko T.S. New principles for the organization of neurorehabilitation. Biomedical Engineering, 2018, no. 52, pp. 9-13. $562 \mathrm{p}$.

14. Rizzo D.C. Fundamentals of anatomy and physiology. Boston, USA, Cengage Learning, 2015.

15. Kublanov V., Aftanas L., Petrenko T., Danilenko K. Investigation of the Neuro-electrostimulation Mechanisms by Means of the Functional MRI: Case Study. Proceedings of the 11th International Joint Conference on Biomedical Engineering Systems and Technologies, 2018, vol. 4, pp. 319-324. DOI: 10.5220/0006712203190324

16. Pelegrina S., Lechuga M.T., García-Madruga J.A., Rosa Elosúa M. Normative data on the n-back task for children and young adolescents. Front. Psychol., 2015, vol. 6: 1544, pp. 1-11.

17. Jaeggi S., Studer-Luethi B., Buschkuehl M., Su Y. The relationship between n-back performance and matrix reasoning - implications for training and transfer. Intelligence, 2010, vol. 38, no. 6, pp. 625-635.

18. Ruf S.P., Fallgatter A.J., Plewnia C. Augmentation of working memory training by transcranial direct current stimulation (tDCS). Sci. Rep., 2017, vol. 7 (1), no. 876, pp. 1-11.

Received 16 April 2021

УдК 303.732 .4

DOI: $10.14529 /$ ctcr210204

\section{ИНФОРМАЦИОННО-ИЗМЕРИТЕЛЬНАЯ СИСТЕМА ДЛЯ КОРРЕКЦИИ ПАРАМЕТРОВ РАБОЧЕЙ ПАМЯТИ В ПРОЦЕССЕ ОБУЧЕНИЯ}

\author{
А.А. Петренко, В.С. Кубланов
}

Уральский федеральный университет имени первого Президента России

Б.Н. Ельцина, г. Екатеринбург, Россия

\begin{abstract}
В настоящей работе приведены результаты системного анализа информационно-измерительной системы (ИИС) для коррекции параметров рабочей памяти добровольцев-испытуемых в процессе обучения, в которой запуск процесса нейропластичности головного мозга осуществляется с помощью стимуляции нервных образований шеи пространственно распре-
\end{abstract}


деленным полем импульсов напряжения, мишенью стимуляции являются шейные ганглии симпатической нервной системы, контроль функциональных изменений в организме осуществляется по данным изменений параметров системы кровоснабжения, а для оценки рабочей памяти используются психометрические тесты. Цель работы: разработка ИИС с использованием нейроэлектростимуляции периферических нервных образований шеи для коррекции параметров рабочей памяти в процессе обучения. Материалы и методы. В исследовании приняли участие 65 добровольцев-испытуемых, разделенных с помощью рандомизации на экспериментальную, контрольную и плацебо группы. Оценка параметров рабочей памяти проводилась с использованием теста dual 2-back, а оценка функционального состояния проводилась с помощью анализа вариабельности сердечного ритма (ВСР). Результаты. Результаты исследования показали, что предложенная структура ИИС и методика коррекции рабочей памяти позволяют улучшать показатели рабочей памяти и нормализовать состояние вегетативной нервной системы после трех процедур коррекции. Полученные результаты по тесту практически не изменяются и сохраняются через 2 месяца. Заключение. ИИС, обеспечивающая многоканальную нейроэлектростимуляцию периферических нервных образований шеи, является эффективной для коррекции когнитивных навыков, что актуально для решения задач из сферы образования.

Ключевые слова: информационно-измерительная система, нейроэлектростимуляция, системный анализ, информация, методы и алгоритмы, когнитивнье характеристики, рабочая память.

\section{Лuтература}

1. Наличаева, С.А. Психология стресса: учеб.-метод. пособие / С.А. Наличаева. - Севастополь: Авангард, 2018. - 97 c.

2. Gupta, P.K. Working Memory and Learning Disabilities: A Review / P.K. Gupta, V. Sharma // The International Journal of Indian Psychology. - 2017. - Vol. 4 (4). - P. 111-121. DOI: $10.25215 / 0404.013$

3. Masoura, E.V. Establishing the link between working memory function and learning disabilities. Learning disabilities / E.V. Masoura // A contemporary journal. - 2006. - Vol. 4 (2). - P. 29-41.

4. Swanson, H.L. Do different components of working memory underlie different subgroups of reading disabilities? / H.L. Swanson, C.B. Howard, L. Saez // Journal of learning disabilities. - 2006. Vol. 39 (3). - P. 252-269.

5. Alloway, T.P. Working memory, but not IQ, predicts subsequent learning in children with learning difficulties / T.P. Alloway // European Journal of Psychological Assessment. - 2009. - Vol. 25 (2). P. 92-98. DOI: 10.1027/1015-5759.25.2.92

6. Лебедев, А.В. Психические прочессы и состояния: метод. пособие для студентов всех спеииальностей / А.В. Лебедев, Ю.А. Жигалов. - СПб.: СПбГАХПТ, 1999. - 124 c.

7. Мандель, Б.Р. Современная педагогическая психология. Полный курс: иллюстрир. учеб. пособие для студентов всех форм обучения / Б.Р. Мандель. - М.; Берлин: Директ-Медиа, 2015. $828 \mathrm{c}$.

8. Brain Waves Module 2: Neuroscience: implications for education and lifelong learning. The Royal Society, 2011.

9. Кубланов, В.С. Электрофизический способ коррекции нарушений системы регуляции кровоснабжения головного мозга / В.С. Кубланов // Биомедиџинская радиоэлектроника. - 1999. № 4. - C. $12-15$.

10. Акулов, С.А. Основы теории биотехнических систем / С.А. Акулов, А.А. Федотов. - М.: Физматлит, 2014. - 259 c.

11. Попечителев, Е.П. Человек в биотехнической системе / Е.П. Попечителев. - Старый Оскол: ТНТ, 2016. - 584 c.

12. Ершов, Ю.А. Основы анализа биотехнических систем: учеб. пособие для студентов высших учебных заведений / Ю.А. Ершов, С.И. Шукин. - М.: МГТУ им. Н.Э. Баумана, 2011. - 526 с.

13. Кубланов, В.С. Новые принциипы организации нейрореабилитации / В.С. Кубланов, М.В. Бабич, Т.С. Петренко // Медицинская Техника. - 2018. - № 1. - C. 6-9.

14. Rizzo, D.C. Fundamentals of anatomy and physiology / D.C. Rizzo. - Boston, USA: Cengage Learning, 2015. $-562 p$. 


\section{Инфокоммуникационные технологии и системы}

15. Investigation of the Neuro-electrostimulation Mechanisms by Means of the Functional MRI: Case Study / V. Kublanov, L. Aftanas, T. Petrenko, K. Danilenko // Proceedings of the 11th International Joint Conference on Biomedical Engineering Systems and Technologies. - 2018. - Vol. 4. - P.319-324. DOI: $10.5220 / 0006712203190324$

16. Normative data on the n-back task for children and young adolescents / S. Pelegrina, M.T. Lechuga, J.A. García-Madruga, M. Rosa Elosúa //Front. Psychol. - 2015. - Vol. 6: 1544. - P. 1-11.

17. The relationship between $n$-back performance and matrix reasoning - implications for training and transfer / S. Jaeggi, B. Studer-Luethi, M. Buschkuehl, Y. Su // Intelligence. - 2010. - Vol. 38, no. 6. P. 625-635.

18. Ruf, S.P. Augmentation of working memory training by transcranial direct current stimulation (tDCS) / S.P. Ruf, A.J. Fallgatter, C. Plewnia // Sci. Rep. - 2017. - Vol. 7 (1), no. 876. - P. 1-11.

Петренко Анна Александровна, старший преподаватель кафедры радиоэлектроники и телекоммуникаций, Уральский федеральный университет имени первого Президента России Б.Н. Ельцина, г. Екатеринбург; a.a.petrenko@urfu.ru.

Кубланов Владимир Семенович, д-р техн. наук, профессор, профессор кафедры радиоэлектроники и телекоммуникаций, Уральский федеральный университет имени первого Президента России Б.Н. Ельцина, г. Екатеринбург; kublanov@mail.ru.

Поступила в редакцию 16 апреля 20212.

\section{ОБРАЗЕЦ ЦИТИРОВАНИЯ}

Petrenko, A.A. Information Measuring System for Correction of Working Memory Parameters in the Learning Processes / A.A. Petrenko, V.S. Kublanov // Becтник ЮУрГУ. Серия «Компьютерные технологии, управление, радиоэлектроника». - 2021. - Т. 21, № 2. C. 36-46. DOI: $10.14529 /$ ctcr210204

\section{FOR CITATION}

Petrenko A.A., Kublanov V.S. Information Measuring System for Correction of Working Memory Parameters in the Learning Processes. Bulletin of the South Ural State University. Ser. Computer Technologies, Automatic Control, Radio Electronics, 2021, vol. 21, no. 2, pp. 36-46. DOI: $10.14529 / \mathrm{ctcr} 210204$ 